JOSETA: Journal of Socio Economic on Tropical Agriculture

Volume 1 Nomor 1: 18-27 April (2019)

JOSETA: Journal of Socio Economic on Tropical Agriculture http://joseta.faperta.unand.ac.id

ISSN : $2686-0953$ (online)

\title{
ANALISIS PERBANDINGAN PENDAPATAN DAN KEUNTUNGAN USAHATANI MINAPADI DENGAN PADI KONVENSIONAL DI NAGARI TALANG MAUR KECAMATAN MUNGKA KABUPATEN LIMA PULUH KOTA
}

\author{
COMPARATIVE ANALYSIS OF INCOME AND BENEFIT \\ MINAPADI FARMING AND CONVENTIONAL PADDY IN NAGARI \\ TALANG MAUR KECAMATAN \\ Milani Kurnia Ilahi, Sri Wahyuni, Yusri Usman \\ ${ }^{1}$ Mahasiswa Program StudiAgribisnis, FakultasPertanian, UniversitasAndalas, Padang \\ ${ }^{2}$ Prodi Agribisnis, FapertaUnand, Padang, sriwahyuni@gmail.com \\ ${ }^{3}$ Agribisnis, FapertaUnand, Padang. \\ Received: $20^{\text {th }}$ Februari, 2019; $1^{\text {st }}$ Revision: $15^{\text {th }}$ Maret, 2019; Accepted: $17^{\text {th }}$ April, 2019
}

\begin{abstract}
Abstrak
Penurunan produktiftas lahan sawah terjadi karena terjadi pergeseran fungsi lahan menjadi fungsi non pertanian. Salah satu cara untuk meningkatkan pendapatan petani adalah dengan mengubah strategi usaha tani yang dilakukan dari pertanian padi conventional ke pertanian minapadi. Tujuan penelitian ini untuk melihat teknik budidaya dan untuk menganalisis perbandingan pendapatan dan keuntungan dari sistem pertanian minapadi dengan pertanian padi konvensional. Data dianalisis secara deskriptif kualitatif dan kuantitatif dengan menggunakan uji t. Hasil analisis menunjukkan bahwa teknik minapadi dengan padi konvensional memiliki persamaan dan perbedaan. Secara umum teknik penanaman minapadi sesuai dengan rekomendasi FAO walaupun masih ada beberapa perberdaan karena kesesuaian lokasi. Sementara teknik penanaman padi konvensional belum dilakukan secara optimal karena petani masih menerapkan kebiasaan yang turun temurun. Hasil uji t menunjukkan terdapat perbedaan yang signifikan antara pendapatan usahatani minapadi dengan usaha tani konvensional dan tidak ada perbedaan signifikan antara keuntungan minapadi dengan usaha tani konvensional.
\end{abstract}

Kata kunci : usahatani minapadi, usahatani padi konvesional, pendapatan, keuntungan

\begin{abstract}
Rice fields as rice production resources are decreasing due to the shifting of land functions to nonagricultural functions. One way that can improve farmers' income is to change the agricultural strategy from conventional rice farming to minapadi farming. The purpose of this study is to see the cultivation technique and to analyze the comparison of income and profit of minapadi farming system with conventional rice farming. Data were analyzed descriptively qualitative and quantitative descriptive by using $t$ test. The result of the analysis shows that minapadi farming techniques with conventional rice have similarities and differences. In general, minapadi cultivation techniques are in accordance with FAO recommendations although there are still some differences due to the suitability of the location. While conventional rice cultivation techniques have not been done optimally because farmers are still applying in accordance with the habits and hereditary. From result of t test, there is significant difference of earnings between minapadi farming with conventional rice farming and there is no significant difference of profit between minapadi farming with conventional rice farming.
\end{abstract}

Keywords: Minapadi Farming, Covensional rice farming, Income and Profits. 


\section{PENDAHULUAN}

Sektor pertanian merupakan salah satu sumber pendapatan yang memiliki peranan penting dalammeningkatkan perekonomian Indonesia. Hal ini disebabkan oleh sebagian besar penduduk Indonesia hidupnya bergantung pada sektor pertanian. BerdasarkanBerdasarkan data BPS pada publikasi Keadaan Angkatan Kerja di Indonesia Agustus 2017(2017), tercatat sebesar 39,67 juta penduduk Indonesia yang berusia 15 tahun keatas bekerja pada sektor pertanian.

Lahan sawah yang subur sebagai sumberdaya lahan utama produksi padi semakin berkurangHal ini diakibatkan adanya pergeseran fungsi lahan tersebut ke fungsi non-pertanian. Menurut Badan Pusat Statistik Sumatera Barat, produksi padi di Sumatera Barat pada tahun 2016 tercatat sebesar 2.503.452 ton. Angka tersebut turun sebesar 1,85 persen dibandingkan produksi padi tahun 2015. Penurunan produksi tersebut diakibatkan oleh kurangnya luas panen sebesar 3,09 persen.

Kegiatan usahatani bertujuan untuk mencapai produksi di bidang pertanian. Pada akhirnya akan dinilai dengan uang yang diperhitungkan dari nilai produksi setelah dikurangi atau memperhitungkan biaya yang telah dikeluarkan. Salah satu jalan keluar yang dapat ditempuhuntuk dapat meninggkatkan pendapatan petani, yaitu dengan merekayasa lahan sempit dengan teknologi yang tepat guna. Salah satu cara yang dapat dilakukan yaitu mengubah strategi pertanian dari usahatani padi konvensional menjadi usahatani minapadi. misalnya dengan Kementerian Kelautan dan Perikanan (KKP) melalui DirektoratJenderal Perikanan Budidaya (DJPB), bekerjasama dengan Food and Agriculture Organitation(FAO) melakukan program percontohan budidaya mina padi di Indonesia pada tahun 2015.

Program percontohan ini merupakan bagian dari upaya Kementrian Kelautan dan Perikanan serta Upaya Kementrian Pertanian, dapat disatukan menjadikan gerakan nasional bersama dalam menciptakan kesejahteraan masyarakat melalui minapadi yang nantinya selain menghasilkan padi juga dapat menghasilkan ikan. Terdapat dua Kabupaten di Indonesia yang terpilih sebagai percontohan budidaya minapadi dalam program ini adalah Kabupaten Sleman di Daerah Istimewa Yogyakarta dan Kabupaten Limapuluh Kota Sumatera Barat (Basuki, 2015).

Panen perdana percontohan minapadi ini dilakukan pada bulan Januari 2016. Setelah dilakukannya panen perdana, terlihat bahwa adanya peningkatan produksi padi. Selain peningkatan produksi padi,beberapa petani mengalami penurunan produksi padi dan juga tidak sama sekali mengalami peningkatan ataupun penurunan produksi padi (tetap). Hal tersebut diakibatkan karena serangan hamatercatat burung dan tikus, mengalami kebanjiran, dan teknik pengelolaan usahatani yang tidak baik.

Budidaya padi bersama ikan juga memiliki kekurangan yaitu tingkat kesulitan dalam persiapan lahannya, pengaturan air dan juga membuat petani melakosikan waktu yang lebih banyak dan rutin untuk mengawasi air atau irigasi. Selain itu sistem minapadi juga memiliki syarat dan ketentuan dalam Teknik budidayanyaagarterhindardarikerugian dan agar dapat meningkatkan pendapatan petani.

Sedangkan usahatani padi konvensional tidak begitu sulit untuk membudidayakannya, karena ketersediaan air secara terus-menerus tidak begitu mempengaruhi terhadapkeberhasilan usahatani padi konvensional dan juga varietas padi untuk usahatani padi konvensional yang sangat beragam.

Usahatani minapadi sudah dilakukan oleh para petani sejak tahun 1950an. Perbedaan minapadi dahalu dengan sekarang yaitu dalam penerapan teknologi yang masih sederhana dan juga masih minimnya pengetahuanpetanidalam menerapkan usahatani minapadi agar dapat meingkatkan pendapatan petani. Sedangkan perbedaan usahatani minapadi dan usahatani padi konvensional juga terlihat pada penggunaan input dan biaya produksi. Dalam usahatani minapadi, input produksi seperti bibit ikan, pakan tambahan dan lain sebagaianya tidak terdapat pada usahatani padi konvensioanal. Haltersebut nantinya akan mempengaruhi tingkat pendapatan usahatani minapadi dan juga usahatani.

Intensifikasi minapadi sejauh ini belum pernah diteliti secara ilmiah apakah benar-benar menguntungkan atau tidak bagi para petani yang menerapkan sistem minapadi di Nagari TalangMaur Kecamatan Mungka Kabupaten Lima Puluh Kota yang nantinya dibandingkan dengan usahatani padi konvensional di daerah tersebut.

Berdasarkan latar belakang dan perumusan masalah diatas, maka penelitian ini bertujuan untuk: 
1. Mendeskripsikan Teknik budidaya minapadi dan padi konvensional di Nagari Talang Maur Kecamatan Mungka Kabupaten Lima Puluh Kota

2. Menganalisis perbandingan pendapatan dan keuntungan usahatani minapadi dengan usahatani konvensional di Nagari Talang Maur Kecamatan Mungka Kabupaten Lima Puluh Kota

\section{METODE PENELITIAN}

Penelitian ini dilakukan di Nagari Talang Maur Kecamatan Mungka Kabupaten Lima PuluhKota. Metode yang digunakan dalam penelitian ini adalah metode pendekatan survei. Menurut Nazir(2005), metode survei adalah metode yang digunakan untukmenyelidiki,membedah dan mengevaluasi keadaan untuk memperoleh fakta dari gejala - gejala yang ada dan mencari keterangan - keterangan secara faktual baik tentang institusi sosial, ekonomi, maupun politik dari suatu kelompok ataupun daerah.

Metode yang digunakan dalam pengambilan sampel untuk usahatani minapadi yaitu dengan metode sensus. Sedangkan metode yang digunakan untuk pengambilan sampel petani padi konvensional menggunakan metode purposive sampling dengan jumlah sampel yang sama dengan petani minapadi yaitu sebanyak 19 petani dan juga menggunakan kriteria luas lahan, varietas, dan musim tanam yang sama dengan usahatani minapadi. Pengambilan sampel yaitu pada musim tanam bulan Mei - Agustus 2016.

Data yang dikumpulkan dalam penelitian ini adalah data primer dan data sekunder yang berhubungan dengan persoalan penelitian ini. Menurut Nazir (1999), data primer adalah data dari sumbersumber dasar, yang merupakan bukti dari kejadian yang lalu. Sedangkan data sekunder adalah data atau catatan tentang adanya suatu peristiwa yang jaraknya telah jauh dari sumber original.

Data primer diperoleh dari key informan yang ditentukan oleh peneliti dan dari petani responden dengan melakukan wawancara langsung menggunakan panduan wawancara. Data Sekunder diperoleh dari literaturyang berasal dari lembaga atau instansi terkait seperti, Dinas Pertanian dan Perikanan Kabupaten Lima Puluh Kota, Badan Pusat Statistik, Wali Nagari Talang Maur dan. Kelompok Tani / KelompokPembudidaya Ikan P3Pdan Kelompok Pembudidaya Ikan Pelita Harapan.

Agar tercapai tujuan yang diinginkan dalam penelitian ini digunakan dua metode analisis data, yaitu analisis deskriptif kualitatif melalui pengamatan langusung di lapangan dan berpedoman kepada anjuran dari literatur. Alat analisis untuk tujuan kedua yaitu deskripstif kuantitatif. Penerimaan usahatani adalah perkalian antara produksi yang diperoleh dengan harga jual, seperti rumus berikut (Soekartawi, 1995):

$\mathrm{TR}=\mathrm{Y} \times \mathrm{PY}$

Keterangan:

$\mathrm{TR}=$ total penerimaan petani $(\mathrm{Rp} / \mathrm{Ha} / \mathrm{MT})$

$\mathrm{Y} \quad=$ produksi yang diperoleh dalam suatu usahatani $(\mathrm{Kg} / \mathrm{Ha})$

$\mathrm{Pi} \quad=$ harga jual komoditi i $(\mathrm{Rp} / \mathrm{Kg})$

Jika komoditas tanaman yang diusahakan adalah lebih dari satu, maka rumus dapat berubah menjadi sebagai berikut(Soekartawi, 1995):

$\mathrm{TR}=\sum_{i=1}^{n} \boldsymbol{Y i} \cdot \boldsymbol{P} \boldsymbol{y} \boldsymbol{i}$

Keterangan:

$\mathrm{n} \quad=$ jumlah komoditi

i1 = padi

i2 = ikan

Pendapatan usahatani adalah selisih antara penerimaan dan semua biaya. Yang dimaksud dengan semua biaya dalam menghitung pendapatan yaitu pendapatan yaitu biaya yang dibayarkan (tunai) dalam proses produksi. Menghitung pendapatan petani selama satu musim tanam dapat digunakan rumus berikut (Soekartawi, 1995) :

$\mathrm{Pd}=\mathrm{TR}-\mathrm{Bt}$ 


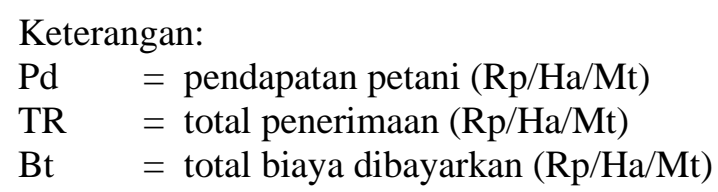

Untuk pendapatan usahatani minapadi, yaitu penerimaan dari padi dan ikan dikurangi dengan biaya yang dibayarkan dalam budidaya padi dan ikan dalam satupetakan sawah. Pendapatan usahatani minapadi dapat dihitung dengan rumus(Soekartawi, 1995):

$\mathrm{Pd}=\sum_{i=1}^{n} \boldsymbol{T R} \boldsymbol{i} \cdot \boldsymbol{B} \boldsymbol{t} \boldsymbol{i}$

Keterangan:

i1 = padi

i2 = ikan

Keuntungan petani atau pendapatan bersih adalah selisih antara penerimaan dengan biaya total. Total biaya adalah seluruh biaya yang digunakan dalam berproduksi, terdiri dari biaya yang dibayarkan dan biaya yang diperhitungkan (Soekartawi, 1995).

$\mathrm{K}=(\mathrm{Yi}$. Pyi $)-\mathrm{BT}$

Keterangan:

$\mathrm{K}=$ keuntungan usahatani $(\mathrm{Kg} / \mathrm{Ha} / \mathrm{MT})$

$\mathrm{Yi}=$ jumlah produksi komoditi $\mathrm{i}(\mathrm{Kg} / \mathrm{Ha} / \mathrm{MT})$

Pyi $=$ harga jual komoditi $\mathrm{i}(\mathrm{Rp} / \mathrm{Kg})$

$\mathrm{BT}=$ total keseluruhan biaya $(\mathrm{Rp} / \mathrm{Ha} / \mathrm{MT})$

Dalam usahatani minapadi, keuntangan yang diperolah yaitu dari hasil produksi padi dan ikan, dapat dihitung dengan rumus(Soekartawi, 1995):

$\mathrm{K}=\sum_{i=1}^{n}$ (Yi.Pyi) $-\boldsymbol{B} \boldsymbol{T} \boldsymbol{i}$

Biaya total dalam menghitung keuntungan yaitu biayayang dibayarkan dijumlahkan dengan biaya yang diperhitungkan dalam proses produksi. Untuk biaya total dalam usahatani minapadi dalam menghitung keuntungan yaitu biaya yang dibayarkan dan biaya yang diperhitungkan dalam budidaya padi dan ikan. Menurut Soekartawi (1995), kesulitan dalam menghitung biaya usahatani biasanya timbul bila tanaman yang diusahakan itu lebih dari satu macam tanaman. Seperti budidaya minapadi, jumlah input yang dipakai tidak diketahui persis diarahkan untuk padi atau ikan. Bila terjadi yang demikian, jumlah fisik input menjadi tidak penting, tetapi yang perlu dicari adalah seberapa besar rupiah (pengeluaran) yangdikeluarkan untuk tanaman tersebut.

Adapun biaya-biaya yang lainnya yang perlu dihitung dalam usahatani yaitu sebagai berikut:

a. Biaya penyusutan

Biaya penyusutan ini dikenakan untuk alat-alat pertanian yang digunakan dalam usahatani.

Rumus perhitungan untuk biaya penyusutan pertahun adalah:

\section{PenyusutanAlat $/$ Thn $=\frac{\text { Investasi }- \text { Nilai Akhir }}{\text { Umur Ekonomis }}$}

b. Bunga modal

(Soekartawi, 1995)

Bunga modal dihitung berdasarkan tingkat suku bunga yang berlaku di daerah penelitian, yaitu berdasarkan bunga pinjaman 14\% / tahun (Bank BRI).

Bunga Modal $=\frac{(\text { BT } \times \mathrm{i})}{12} \times$ Lama MT

Keterangan:

BT = biaya total sebelum bunga modal $(\mathrm{Rp} / \mathrm{Ha} / \mathrm{MT})$

I = tingkat suku bunga

MT = lama musim tanam 
Untuk melihat besarnya perbandingkan pendapatan dan keuntungan usahatani minapadi dengan usahatani padi konvensional digunakan analisis statistik. Menurut Supranto (1994), uji t digunakan untuk menguji hipotesis mengenal nilai parameter, paling banyak dari 2 populasi dengan sampel yang kecil (misalnya $\mathrm{n}<100$, bahkan seringkali $\mathrm{n} \leq 30$ ).

Variabel yang dianalisis secara statistik adalah pendapatan dan keuntungan. Dimana hipotesa penelitian adalah sebagai berikut:

H0 : Tidak terdapat perbedaan pendapatan antara usaha tani mina padi dengan padi konvensional.

H1 : Terdapat perbedaan pendapatan antara usahatani minapadi dengan padi konvensional.

H0 : Tidak terdapat perbedaan keuntungan antara usahatani minapadi dengan padi konvensional

H1 : Terdapat perbedaan keuntungan antara usahatani minapadi dengan padi konvensional.

Hipotesa tersebut diuji dengan uji t (t-test) pada taraf 5\% dengan rumus sebagai berikut:

$t_{\text {hit }}=\frac{\bar{X}_{1}-\bar{X}_{2}}{\sqrt{\left(n_{1}-1\right) S_{1}^{2}+\left(n_{2}-1\right) S_{2}^{2} x\left(\frac{1}{n_{1}}+\frac{1}{n_{1}}\right)}}$

Keterangan:

$\bar{x}_{1}=$ rata-rata pendapatan dan keuntungan usahatani minapadi

$\bar{x}_{2}=$ rata-rata pendapatan dan

keuntungan usahatani padi konvensional

$s_{1}^{2}=$ standar deviasi usahatani minapadi

$s_{2}^{2}=$ standar deviasi usahatani padi konvensional

$n_{1}=$ jumlah petani sampel usahatani minapadi

$n_{2}=$ jumlah petani sampel usahatani padi konvensional

Kriteria keputusan pengujian:

1) Apabila $\mathrm{T}$ hitung $\leq \mathrm{T}$ tabel, maka $\mathrm{H} 0$ Diterima (Tolak $\mathrm{H}_{1}$ ), artinyatidak terdapat perbedaan pendapatan dan keuntungan usahatani midapadi dengan padi konvensional.

2) Apabila $T$ hitung $>T$ tabel, maka $\mathrm{H} 0$ Ditolak (Terima $H 1$ ), artinya terdapat perbedaan pendapatandankeuntunganusahatanimidapadi dengan padi konvensional.

\section{HASIL DAN PEMBAHASAN}

\section{Gambaran Perbedaan Budidaya Mina padi dengan Padi Konvensional}

Teknis budidaya minapadi di Nagari Talang Maur pada umumnya didasari oleh Petunjuk Teknis (Juknis) atau buku panduan yang diterbitkan oleh FAO bekerjasama dengan Dirjen Perikanan Budidaya untuk program daerah percontohan minapadi di dua kabupaten di Indonesia. Buku panduan tersebut berjudul Technical Manual On Inovative Rice-Fice Farming Technology And Practise. Pembuatan buku panduan tersebut bertujuan untuk memfasilitasi dalam mewujudkan tahapan dalam penerapan budidaya minapadi dari awal sampai akhir dan juga produksi ikan diperkirakan akan mencapai lebih dari 2 ton per hektar sawah, sedangkan produksi padi tidak berkurang dan keuntungan petani bertambah. Akan tetapi, buku panduan tersebut hanya berfokus pada budidaya ikan dan untuk padi hanya terfokuskan setelah lahan sawah tersebut di gabung dengan budidaya ikan (minapadi).

Perbedaan budidaya padi konvensional dengan minapadi yaitu terletak pada pola tanamnya. Pola tanam padi konvensional yaitumonokultur dan minapadi menerapkan pola polikultur. Pada usahatani padi konvensional komoditi yang dibudidayakan hanya tanaman padi saja, sedangkan pada usahatani minapadi komoditi yang dibudidayakan yaitu tanaman padi dan ikan. Dari sana terlihat bagaimana perbedaan perlakuan terhadap tanaman padi saja atauperlakukan terhadap tanaman padi dan 
ikan. Teknik budidaya mina padi dengan padi konvensional memeiliki persamaan dan perbedaan. Ada beberapa kegiatan yang ada di usahatani minapadi tetapi tidak ada di usahatani padikonvensional, sebaliknya kegiatan yang tidak ada di usahatani minapadi tetapi ada di usahatani padi konvensional. Untuk lebih jelasnya dapat dilihat pada Tabel 1.

Tabel 1. Perbandingan Teknik Budidaya Usahatani Minapadi dan Padi Konvensional

\begin{tabular}{|c|c|c|c|c|}
\hline No & & Teknik Budidaya & Minapadi & $\begin{array}{c}\text { Padi } \\
\text { Konvensional }\end{array}$ \\
\hline 1. & $\begin{array}{l}\text { Pengolahan } \\
\text { Lahan }\end{array}$ & $\begin{array}{ll}\text { a. } & \text { Pembersihan dan } \\
& \text { Perbaikan pematang } \\
\text { b. } & \text { Pembajakan / } \\
& \text { Pencangkulan } \\
& \text { Pembuatan pintu air khusus } \\
\text { c. } & \text { (bamboo/paralon) } \\
\text { d. } & \text { Pembuatan kamir } \\
\end{array}$ & $\begin{array}{l}\sqrt{ } \\
\sqrt{ } \\
\sqrt{ }\end{array}$ & - \\
\hline 2. & Persemaian & $\begin{array}{l}\text { Penebaran benih merata } \\
\text { Jenis varietas } \\
\text { (junjuang/kuniang) }\end{array}$ & $\sqrt{ }$ & $\sqrt{ }$ \\
\hline 3. & Penanaman padi & $\begin{array}{ll}\text { ia. } & \text { Umur bibit (20 - } 40 \text { hari) } \\
\text { b. } & \text { Sistem tanam } \\
\text { c. } & \text { Jarak tanam }(\mathrm{cm}) \\
\text { d. } & \text { Jumlah bibit per lobang }(2-3 \text { bayang } \\
\text { e. } & \text { Kedalaman lobang tanam }(2-3 \mathrm{~cm}) \\
\text { f. } & \text { Waktu penanaman (pagi dan sore }) \\
\end{array}$ & $\begin{array}{c}\sqrt{ } \\
\text { Jajar lego } 4: 1 \\
40 \times 20 \times 20 \\
\sqrt{ } \\
2-5 \\
\sqrt{ }\end{array}$ & $\begin{array}{c}\sqrt{ } \\
\text { Tegel } \\
25 \times 25 \\
\sqrt{ } \\
2-5 \\
\sqrt{ }\end{array}$ \\
\hline 4. & Penebaran ikan & Menebarkan ikan & $\sqrt{ }$ & - \\
\hline 5. & $\begin{array}{l}\text { Pemberian } \\
\text { pakan ikan }\end{array}$ & Memberi pakan ikan & $\sqrt{ }$ & - \\
\hline 6. & Pemupukan & $\begin{array}{l}\text { a. Jumlah pemberian pupuk organik } \\
\text { b. Jumlah pemberian pupuk kimia }\end{array}$ & $\begin{array}{c}\text { Banyak } \\
\text { Sedikit }\end{array}$ & $\begin{array}{l}\text { Sedikit } \\
\text { Banyak }\end{array}$ \\
\hline 7. & $\begin{array}{l}\text { Peyulaman dan } \\
\text { penyiangan }\end{array}$ & $\begin{array}{l}\text { Melakukan penyulaman } \\
\text { Melakukan penyiangan }\end{array}$ & - & $\begin{array}{l}\sqrt{ } \\
\sqrt{ }\end{array}$ \\
\hline 8. & Pengairan & $\begin{array}{ll}\text { a. } & \text { Persemaian } \\
\text { b. } & 11 \text { HST-menjelang berbunga } \\
\text { c. } & \text { Fase berbunga - 10 HSP padi } \\
\text { d. } & \text { Panen ikan (10 HSP padi) } \\
\text { g. } & 10 \text { HSP padi -panen padi } \\
\end{array}$ & $\begin{array}{c}\text { Mecak - mecak } \\
\text { Mecak - mecak } \\
4-6(\mathrm{~cm}) \\
\text { Dikeringkan } \\
\text { Dikeringkan pada } \\
\text { bagian permukaan } \\
\text { padi } \\
\end{array}$ & $\begin{array}{c}\text { Mecak - mecak } \\
\text { Mecak - mecak } \\
3-5(\mathrm{~cm}) \\
-\end{array}$ \\
\hline 9. & $\begin{array}{l}\text { Pemasangan } \\
\text { pagar }\end{array}$ & Memasang pagar (waring) & $\sqrt{ }$ & - \\
\hline 10. & Pengendalian & $\begin{array}{l}\text { Jenis hama / Gulma } \\
\text { Cara pemberantasan hama }\end{array}$ & $\begin{array}{c}\text { Berang - berang } \\
\text { (Keladi air) } \\
\text { Pestisida dan } \\
\text { Diusir }\end{array}$ & $\begin{array}{l}\text { Walang sangit, } \\
\text { tikus, dan keong } \\
\text { Pestisida dan } \\
\text { Dibuang }\end{array}$ \\
\hline 11. & Pemanenan & $\begin{array}{ll}\text { a. } & \text { Pemanenan ikan } \\
\text { b. } & \text { Pemanen padi }\end{array}$ & $\begin{array}{l}\sqrt{ } \\
\sqrt{ }\end{array}$ & - \\
\hline
\end{tabular}


Keterangan:

(HSbT) Hari Sebelum Tanam

(HST) Hari Setelah Tanam

(HSP) Hari Sebelum Panen

\section{Analisis Perbandingan Pendapatan dan Keuntungan Usahatani Minapadi dengan Padi Konvenisonal}

1. Produksi

Produksi dari usahatani minapadi dan padi konvensional untuk setiap musim tanamnya dihitung dengan menggunakan satuan $\mathrm{Kg} / \mathrm{ha} / \mathrm{MT}$. Dari hasil penelitian diketahui bahwa produksi antara usahatani minapadi dengan padi konvensional itu berbeda. Usahatani minapadi menghasil komoditi padi dan ikan, sedangkanusahatani padi konvensional menghasilkan komoditi padi saja. Usahatani minapadi mengghasilkan rata-rata produksi padi adalah $5344 \mathrm{Kg} / \mathrm{Ha} / \mathrm{MT}$. Selain menghasilkan padi, usahatani minapadi juga menghasilkan ikan dengan rata-rata produksi sebesar $985 \mathrm{Kg} / \mathrm{Ha} / \mathrm{MT}$. Sedangkan rata-rata produksi padi pada usahatani padi konvensional adalah $5210 \mathrm{Kg} / \mathrm{Ha} / \mathrm{MT}$.

2.Harga

Harga yang digunakan dalam analisis usahatani adalah harga yang berlaku di pasaran pada saat periode musim tanam. Petaniresponden pada umumnya membudidayakan padi varietas Junjuang atau Padi Kuniang dengan harga gabah yang sama yaitu Rp 5000/Kg. Sedangkan untuk harga ikan nila yaitu $\mathrm{Rp} 17.000$ / Kg. Menurut informan kunci, penetapan harga ikan sesuaikesepakatan petani dengan pedagang dan juga berdasarkan ukuran dan jenis ikan. Namun didaerahpenelitian,biasanyapedagang menetapkan harga ikan nila $\mathrm{Rp} 17.000 / \mathrm{Kg}$.

3. Penerimaan

Penerimaan merupakan nilai yang diterima petani dari hasil usahataninya. Dari hasil penelitian diperoleh penerimaan rata-rata petani minapadi perluas lahan adalah $\mathrm{Rp}$ 13.127.842. Jumlahtersebut merupakan total penerimaan dari hasil penjumlahan penerimaan padi dan ikan.Sedangkan rata-rata total penerimaan usahatani minapadi per hektar adalah Rp 43.467.531. Pada usahatani padi konevensional, penerimaan berasal dari tanaman padi saja. Rata - rata penerimaan petani padi konvensional per luas lahan adalah $\mathrm{Rp}$ 8.107.895. untuk rata-rata penerimaan petani padi konvensional per hektar adalah $\mathrm{Rp}$ 26.047.964.

4. Biaya Produksi

Biaya yang dibayarkan merupakan biaya yang benar-benar dikeluarkan oleh petani dalam melaksanakan proses produksi. Biaya yang dibayarkan usahatani minapadi terdiri dari biaya bibit ikan, biaya pupuk, biaya pestisida, biaya tenaga kerja luar keluarga, biaya pakan ikan, biaya Pajak Bumi dan Bangunan (PBB), biaya panen, serta biaya bagi hasil padi dan ikan. Sedangkan biaya yang dibayarkan pada usahatani padi konvensional terdiri dari biaya pupuk, biaya pestisida, biaya tenaga kerja luar keluarga, biaya Pajak Bumi dan Bangunan (PBB), biaya panen padi dan biaya bagi hasil.

Biaya yang diperhitungkan merupakan biaya yang tidak dibayarkan secara langsung oleh petani, tetapi biaya ini hanya diperhitungkan untuk menentukankeuntungan yang diperoleh petani dari usahatani minapadi dan padikonevnsioanl. Biaya yang diperhitungkan pada usahatani minapadi dan padi konvensional terdiri dari biaya benih, biaya tenaga kerja dalam keluarga, biaya penyusutan alat, dan biaya lahanmilik sendiri. Untuk lebih lengkapnya dpat dilihat pada Tabel 2.

5. Pendapatan

Pendapatan merupakan selisih antara penerimaan dengan biaya yang dibayarkan selama satu musim tanam. Pendapatan rata-rata petani per luas lahan per musim tanam pada usahatani padi minapadi adalah Rp 8.519.256 dan rata-rata per hektar per musim tanam adalah Rp 27.878.548. Sedangkan pendapatan paetani rata-rata per luas lahan per musim tanam pada usahatani padi konvensional adalah Rp 5.347.272 dan per hektarnya adalah Rp 17.471.414.

Dapat disimpulkan bahwapendapatan petani usahatani minapadi lebih besar dibandingkan dengan usahatani padi konvensional, baik per luas lahan maupun per hektar. Hal tersebut dikarekan produksi usahatani minapadi yang menghasilkan dua komoditi yaitu padi dan ikan. Walaupun biaya yang 
dibayarkan pada usahatani minapadi lebih besar dari pada usahatani padi konvensional, namun dengan produksi yang besar akan mempengaruhi tingkat pendapatan petani minapadi.

6. Keuntungan

Keuntungan merupakan selisih dari penerimaan usahatanidengankeseluruhanbiaya. Keseluruhan biaya maksudnya adalah total biaya dari penjumlahan biaya yang dibayarkan dan biaya yang diperhitungkan. Total biaya pada usahatani minapadi perluas lahan adalah Rp 8.208.968 dan per hektar Rp29.093.022/Ha/MT. Sedangkan total biaya pada usahatani padi konvensional perluas lahan adalah Rp 3.749.397 dan per hektar Rp12.066.952/Ha/MT. Untuk menghitung keuntungan petani, maka penerimaan dikurangi dengan total biaya yang dikeluarkan. Rata-rata keuntungan pada usahatani minapadi per luas lahan permusim tanam adalah Rp 6.590.243 dan per hektar Rp 14.327.702. Keuntungan usahatani padi konvensional per luas lahan per musim tanam adalah Rp 4.358.498 dan per hektar adalah Rp 13.981.012.

\section{Uji Statistik (Uji t)}

Dari hasil pengujian statistik diketahui bahwa perbandingan pendapatan usahatani minapadidengan padi konvensional menghasilkan t hitung 2,25, sedangkan t tabel pada tingkat taraf nyata5\% adalah 2,1009. Dari pengujian statistik tersebut terlihat bahwa t hitung lebih besar dibandingkan t tabel. Secara statistik H0 ditolak dan H1 diterima.Dengan demikian dapat disimpulkan bahwa terdapat perbedaan pendapatan usahatani minapadi dengan padi konvensional. Berdasarkan hasil pengujian statistik diketahui bahwa perbandingan keuntungan usahatani minapadi dengan padi konvensional menghasilkan $t$ hitung 0,252 , sedangkan t tabel pada tingkat taraf nyata $5 \%$ adalah 2,1009 . Dari pengujian statistik tersebut terlihat bahwa t hitung lebih kecil dibandingkan $\mathrm{t}$ tabel. Secara statistik H0 diterima dan H1 ditolak. Dengan demikian dapat disimpulkan bahwa tidak terdapat perbedaan yang signifikan antara keuntungan usahatani minapadidibandingkan denganpadikonvensional. Hal tersebut dikarenakan tingginya biaya yang yang diperhitungkan pada usahatani minapadi, yaitu biaya tenaga kerja keluarga yang memerlukan curahan tenaga kerja yang intensif, mempengaruhi besarnya total biaya usahatani walaupun penerimaannya usahatani minapadi besar.

Tabel 2. Perbandingan Pendapatan dan Keuntungan Usahatani Minapadi dengan Padi Konvensional di Nagari Talang Maur Kecamatan Mungka Per Luas Lahan dan PerHektar Msuim Tanam Mei - Agustus 2016

\begin{tabular}{|c|c|c|c|c|c|}
\hline \multirow{2}{*}{ No } & \multirow{2}{*}{ Uraian } & \multicolumn{2}{|c|}{ Minapadi } & \multicolumn{2}{|c|}{ Padi Konvensional } \\
\hline & & Luas Lahan & Hektar & Luas Lahan & Hektar \\
\hline 1 & Harga (Rp) & & & & \\
\hline & a. Padi & 5.000 & 5.000 & 5.000 & 5.000 \\
\hline & b. Ikan & 17.000 & 17.000 & - & \\
\hline 2 & Produksi (Kg) & & & & \\
\hline & a. Padi & 1623 & 5344 & 1622 & 5210 \\
\hline & b. Ikan & 295 & 985 & - & \\
\hline 3 & Penerimaan (Rp) & 13.127.842 & 43.467.531 & 8.107.895 & 26.047 .964 \\
\hline 4 & Biaya Dibayarkan (Rp) & & & & \\
\hline & a. Bibit ikan & 271.053 & 899.565 & - & \\
\hline & b. Pupuk & 252.783 & 1.082 .842 & 127.158 & 402.270 \\
\hline & c. Pestisida & 4.079 & 18.737 & 6.053 & 20.797 \\
\hline & d. TKLK & 413.000 & 1.462 .748 & 125.000 & 378.784 \\
\hline & e. Pakan Ikan & 2.569 .737 & 8.875 .038 & - & \\
\hline & f. $\quad$ PBB & 732 & 2053 & 763 & 2657 \\
\hline & g. Panen padi & 1.623 .105 & 5.344 .449 & 1.621 .579 & 5.209 .593 \\
\hline & h. Panen ikan & 87.658 & 324.067 & - & \\
\hline & i. Bagi hasil lahan & 950.877 & 3.823 .158 & 879.649 & 2.562 .448 \\
\hline
\end{tabular}




\begin{tabular}{|c|c|c|c|c|c|}
\hline & Bagi hasil ikan & 106.932 & 438.653 & - & \\
\hline \multicolumn{2}{|r|}{ Total $(\mathbf{R p})$} & 6.279 .955 & 22.357.198 & 2.760 .623 & 8.576 .550 \\
\hline \multirow[t]{5}{*}{5} & Biaya Diperhitungkan (Rp) & & & & \\
\hline & a. Benih padi & 27.042 & 99.153 & 32.421 & 115.285 \\
\hline & b. TKDK & 1.096 .800 & 4.299 .602 & 209.026 & 762.059 \\
\hline & c. Penyusutan alat & 126.879 & 424.627 & 22.063 & 86.742 \\
\hline & d. Milik sendiri & 678.947 & 1.894 .737 & 725.263 & 2.526 .316 \\
\hline
\end{tabular}

\section{KESIMPULAN}

Berdasarkan hasil penelitian tentang perbandingan pendapatandan keuntungan usahatani minapadi dengan padi konvensional di Nagari Talang Maur Kecamatan Mungka Kabupaten Lima Puluh Kota, dapat diambil kesimpulan sebagai berikut:

1. Teknik budidaya usaha tani minapadi dengan padi konvensional memiliki persamaan dan perbedaan. Persamaannya yaitu pada proses persemaian dan pemanenan padi. Sedangkan perbedaannya yaitu pada proses pengolahan lahan, penanaman padi, pengaturan air, pengaturan air,pengendalian hama dan penyakit tanaman. Kegiatan yang tidak terdapat pada usahatani minapadi yaitu penyuluman dan penyiangan, sedangkan pada usahatani padi konvensional kegiatan yang tidak ada yaitu kegiatan yang berhuungan dengan budidaya ikan seperti pembuatan kamalir, pembuatan pintu air dengan pipa, penebaran bibit ikan, pembuatan pagar, pemberian pakan, dan pemanenan ikan. Pada umumnya teknik budidaya minapadi usdah sesuai dengan anjuran dari FAO walaupun masih ada beberapa perbedaan di karenakan kesesuaian lokasi. Sedangkan teknik budidaya padi konvensional belum dilakukan secara optimal dikarenakan petani masih menerapkan sesuai dengan kebisaan dan didasarkan pada pengalaman berusahatani yang dilakukan secara turun-temurun

2. Terdapat perbedaan yang signifikan antara pendapatan ushatani minapadi dengan padi konvensional berdasarkan uji t-test yang dilakukan. Rata-rata pendapatan usahatani minapadi per hektarnya adalah $\mathrm{Rp} 27.878 .548 / \mathrm{Ha} / \mathrm{MT}$, sedangkan pendapatan usahatani padikonvesnional adalah Rp 17.471.414/Ha/MT. Dari hasil uji t-test, tidak terdapat perbedaanyang signifikan antara keuntungan usahatani minapadi dengan padi konvensional. Rata-rata keuntungan usahatani minapadi per hektarnya adalah Rp 21.142.744/Ha/MT dan keuntungan usahatani padi konvensional per hektarny adalah Rp 13.981.012/Ha/MT.

Berdasarkan penelitian yang telah dilakukan mengenai analisis perbandingan pendapatan dan keuntungan usahatani minapadi dan padi konvensional sehingga muncul beberapa saran yaitu Adanya inovasi dari pemerintah yang lebih efektif dan efisien dalam teknologi pemberian pakan ikan, agar jumlah pellet dan tenaga kerja yang digunakan dapat diminimalisir. Petani harus lebih memperhatikan kondisi air dan hewan pemakan ikan (berang-berang) yang masuk ke lahan sawah pada usahatani minapadi, agar resiko kematian atau kehilangan ikan dapat dihindari. Pemerintah diharapkan dapat memberikan bantuan peralatan untuk kegiatan pengolahan lahan dan pemanenan pada usahatani minapadi dan padi konvensional

\section{UCAPAN TERIMA KASIH}

Ucapan terima kasih ditujukan kepada pembimbing Dosen Prodi Agribisnis yang telah membimbing selama pelaksanaan penelitian 


\section{Daftar Pustaka}

AKK.1990. Budidaya Tanaman Padi.Jakarta : Kanisius

Andoko, A.2002. Budidaya Padi Secara Organik.Jakarta:Penebar Swadaya

Balitbangtan. 2016. Petunjuk Teknis Budidaya Padi Jajar Legowo Super.Kementrian Pertanian. Jawa Barat : Agro Inovasi

Basuki, Fajar. 2015. Technical Manual On Inovate Rice-Fish Farming Teknology And Practice. Direktorat Jenderal Perikanan dan Budidaya

BPS.2017. Sumatera Barat Dalam Angka . Sumatera Barat

BPS Badan Pusat Statistik. 2017. Keadaan Angkatan Kerja di Indonesia Agustus 2017. BPS Press: Jakarta.

Daniel, Moehar.2002. Pengantar Ekonomi Pertanian. Jakarta

Frei M, Becker K.2005 Integratedrice-fish culture :coupled production saves resources. Natural Resources Forum.29:135-143

Hadi, Pdan Pudji, Umi, A. 2014. Pemeliharaan Ikan Bersama Padi Di Sawah (Mina Padi), Sebuah Potensi Keuntungan Ganda Untuk Petani Di Provinsi Bengkulu. Litbang Pertanian Bengkulu

Hadisapoetra, S. 1973. Biaya dan Pendapatan Usahatani. Yogyakarta:Universitas Gajah Mada

Handojo, FL. 1989. Mina Padi. Jakarta : CV Simplex

Hernanto, F. 1989. Ilmu Usahatani. Jakarta : Penebar Swadaya

Nazir. 2005.Metoda Penelitian.Bogor : Ghalia Indonesia

Nurhayati,A.2013. Analisis Integrasi Padi Ikan Dalam Perspektif Agroekosistem. Universitas SultanAgung.Serang - Banten.

Nurhayati, Atikah. Rustikawati, Ike. Maulina, Ine. 2013. Analisis Optimalisasi Minapadi Yang Berkelanjutan (Suatu Kasus di Kecamatan Ciparay Kabupaten Bandung Provinsi Jawa Barat). [Skripsi]. Universitas Padjajaran

Nuryasri,dkk.2015.Kajian Pegembangan Usaha Budidaya Ikan Air Tawar Dalam Mina Padi di Desa

Purwono dan Purnawati. 2007. Budidaya 8 Jenis Tanaman Panggan Unggul. Jakarta :Penebar Swadaya (halaman 3) Rancangan Pembangunan Jangka Menengah.Nagari TalangMaur 2016 - 2021

Rizki, DJ. 2017. Analisis Pendapatan Usahatani Mina padi Di Desa Margoluwih Kecamatan Seyegan, Kabupaten Sleman [Skripsi]. IPB Repository

Singarimbun dan Effendi. 1989. Metode Penelitian Survey. Jakarta : LP3ES

Soekartawi.1995.Analisis Usahatani. Jakarta : Universitas Indonesia Press (UI-Press)

Soeharjo,A.1991. Sendi- Sendi Pokok Ilmu Usahatani. Departemen Ilmu-Ilmu Sosial Ekonomi $\quad$ Fakultas Pertanian Bogor (IPB)

Sudirman dan Iwan. 2009. Minapadi (Budidaya Ikan Bersama Padi). Jakarta : Penebar Swadaya

Sugiyono.2005. Statistik Untuk Penelitian. Bandung : Alfa Beta

Sunarno. 2004. Analisis Pendapatan dan Optimalisasi Pola Tanam Komoditi Sayuran di Desa Sukatani, Kecamatan Pecet,Kabupaten Cianjur, ProvinsiJawa Barat [Skripsi]. Bogor :Fakultas Pertanian, Institut Pertanian Bogor

Supranto, J. 1994. Statistik Teori dan Aplikasi.Jakarta:Erlangga

Suratiyah,K.2008.Ilmu Usaha Tani. Jakarta : Penebar Swadaya

Utama, Z.H. 2015.Budiddaya Padi Pada Lahan Marginal : Kiat Menikatkan Produksi Padi.Yogyakarta : Andi Offset

Vanessa, Gilda. 2008. Analisis Pendapatan Usahatani Padi Sawah Menurut Sistem Mina Padi Dan Sistem Non Mina Padi (Kasus Desa Tapos Dan Desa Taposli, KecamatanTenjolaya,Kabupaten Bogor, Jawa Barat)[Skripsi].IPB Repository

Wirartha,Made. 2006. Metode Penelitian Sosial Ekonomi.Yogyakarta :Andi Offset

Zayin, M dan Suwardi.2016. Kelompok Tani Program Intensifkasi Sistem Mina Padi (Insismindi). Politeknik Negeri Jember

Zuliyanti, Amelia. 2016. Teknologi Budidaya Ikan Nila dan Ikan Gurami di Lahan Pasang Surut [Skripsi]. Fakultas Pertanian. Univrsitas Sumatera Utara 